Science Life

\title{
PRE-BREEDING COLLABORATION IN THE NORDIC-BALTIC REGION
}

\author{
Anders Nilsson
}

LTJ Faculty, Swedish University of Agricultural Sciences, P O Box 53, SE-230 53 Alnarp, SWEDEN

\begin{abstract}
A Nordic Public-Private Partnership (PPP) for Pre-breeding is in place since 2011. Its establishment and scope is presented. Also Baltic plant breeding can participate in the PPP. At a workshop in connection to the $75^{\text {th }}$ anniversary of State Stende Cereal Breeding Institute the first steps were taken in the development of a Concept note for the continued development of the PPP for pre-breeding collaboration in the Nordic-Baltic region. The need for strong prioritisation among efforts to be presented was emphasised in the workshop.
\end{abstract}

\section{INTRODUCTION}

A changing climate will lead to new requirements on the plants we are cultivating in different biologic production systems, in agriculture and horticulture as well as in forestry. With higher temperatures, the areas where many species can be used in agricultural and horticultural production systems will move to the north. This goes as well for pathogens and pests, which are threatening the cultivated crops. It is also anticipated that we will have a higher frequency of situations with extreme weather situations - drought, flooding and cold spells, etc. The only factor influencing the demands on the crops we utilise that will remain unchanged in different parts of the Nordic-Baltic region is the light regime. But during the same time, as these scenarios for the future have developed, there has been a steady decline in the efforts to bring results from plant breeding research into variety development in plant breeding in our region. The global commercial plant breeding companies are more and more focusing on the development of new varieties in crops with good margins for the large markets, such as maize, hybrid oil seed rape, sugar beets and other hybrid crops. Companies in the Nordic-Baltic region have closed down several of their smaller breeding programmes and focus on crops that make up the major part of their respective businesses - wheat, barley, oilseed rape and forages — in their commercial activities. They also have less room to invest in more long-term activities, such as introducing new genetic variation in the utilised gene pools and new resistance genes from distant sources. The breeding efforts supported by public funding, variety generation in crops or for markets that can't carry the costs for breeding, as well as more long-term activities supporting what's going on in the companies, have also dwindled in many of the countries in the region.

This was the situation when Professor Roland von Bothmer and Research Advisor Anders Nilsson were commissioned by the Nordic Council of Ministers (NMR) to look into what should be done to support Nordic plant breeding in joint efforts from the Nordic countries. The commission was initiated from the Swedish Ministry of Agriculture as part of the agenda for the Swedish Presidency of NMR in 2008.

\section{MEASURES TO PROMOTE NORDIC PLANT BREED- ING}

The findings from the commission were developed in a report (von Bothmer and Nilsson, 2010), based on a number of meetings with breeding companies, authorities and stake holders in the Nordic countries. The report was later on, in the same year, supplemented with a memo "Collaboration between Baltic and Nordic Plant Breeding". In summary the following measures were proposed:

- Establishment of a Nordic Public-Private Partnership (PPP) for Pre-breeding with pre-breeding defined as activities aimed at broadening the genetic base for the breeding of a certain crop, at introduction of specific traits in an adapted genetic background, or at development of tools for selection (see below).

- Enabling Baltic plant breeding to participate in the proposed PPP.

- The training of new plant breeders in appropriate PhD-programmes where skills in plant breeding and plant breeding research are combined with molecular aspects and genomics as well as plant pathology and practical aspects on plant breeding. This recommendation has been brought forward to academia.

- Efforts to increase collaboration between non-commercial breeding programmes, specifically regarding the breeding of fruits and berries, which is entirely publicly funded in Finland, Norway and Sweden. A split of responsibilities and work packages between the three in- 
volved breeding entities MTT Horticulture, Graminor and SLU was developed, based on this recommendation, but has not been implemented since one of the parties has decided to continue as before.

\section{ESTABLISHMENT OF A NORDIC PPP FOR PRE- BREEDING}

The report and the recommendations from the commission led to the establishment of a Nordic PPP for Pre-breeding in 2011 (Public Private Partnership, 2011). All five Nordic countries decided to pool their input to the PPP with a budget of 4 million DKR/year for a pilot phase in 2011-2013. Twelve private and public breeding entities decided to join the PPP, and only one entity refrained. The PPP is based on the following principals:

- The PPP is funded 50/50 by the Nordic states and the breeding entities participating in the respective projects.

- The rationale for the PPP is to jointly support the long-term development of plant breeding for the Nordic countries in order to meet the needs for adaptation to Climate Change, ambitions in environmental policies and competitiveness of the production.

- The scope of the PPP is pre-commercial activities of pre-breeding as defined in the report leading to the PPP.

- A Steering Committee composed of representatives from the five Nordic countries, the breeding entities and the Nordic agricultural universities is deciding upon funding of projects, administration of the PPP and reporting on the development of the PPP to NMR.

- The administration of the PPP is handled by NordGen.

- Contribution from the breeding entities can also be made in kind, making the total available budget for the pilot phase 24 million DKR.

- In order to ensure that the projects funded by the PPP are based on the needs of the Nordic plant breeding community, proposals on projects can only be made by breeding entities that have joined the PPP.

- Participation from breeding entities in the Baltic countries is encouraged, but has to be funded from the participating country.

- The scientific quality of the proposals is evaluated by international, non-Nordic expertise.

- An evaluation of the PPP shall be carried out in 2013 as the basis for decisions on its continuation.

As part of the discussions during the investigation on measures to be proposed the Nordic plant breeding companies engaged in the breeding of cereals prepared a list of five different pre-breeding activities that would benefit the longterm development of their breeding of these crops. This list was by itself a token on the willingness of the breeding companies to collaborate. Thus, the Steering Committee decided to open up a Call for the pilot phase on three projects, for barley, forages and apples, respectively. Topics were chosen so that as many breeding entities that had joined the PPP as possible could participate and, also, both private and public plant breeding. Initiated projects are:

Barley. The project "Combining Knowledge from Field and from Laboratory for Pre-breeding in Barley" is in its initial phase aiming to develop new and use available molecular markers to screen current breeding material for traits related to important diseases and abiotic stresses. For the verification of already published and available molecular markers these will be tested on a panel of advanced lines. For development of new markers association mapping based on field data from phenotyping of the traits to be studied and data from high-throughput SNP genotyping will be used. Preparations for marker assisted pre-breeding will be performed for a prolongation of the project after 2013. All Nordic barley breeders will participate as partners in the project, and also University of Copenhagen. The developed data as well as the panel of advanced lines will eventually become available from NordGen.

Forages. The project "PPP for pre-breeding in perennial ryegrass" aims at broadening the basis for the development of cultivars of perennial ryegrass (Lolium perenne L.) with a suitable adaptation to future climates in the Nordic countries. The initial phase will include phenotyping of a panel of gene bank accessions and winter hardy existing cultivars. Based on gained information broad breeding populations will be established and genetic analyses of the material initiated, aiming at identifying marker-trait associations that can be used in the further breeding. In subsequent years these regional-specific populations can be used for cultivar development. All Nordic forage breeders are involved in the project as well as the Jõgeva Plant Breeding Institute, UMB and University of Aarhus. Data as well as material will eventually be available from NordGen.

Apple. The project "Prebreeding for Future Challenges in Nordic Apples (NORDAPP)" will now focus on phenotyping of susceptibility to apple canker and storage rots in a set of selected cultivars and advanced breeding material. Gained information will later be used for the development of molecular markers to be used for selection in the breeding. Obtained results will be channelled into the FP7 project "Fruitbreedomics" for exchange of information. The three entities involved in plant breeding of apples in the Nordic countries, all with public funding, are participating in the project.

\section{DEVELOPMENT OF THE PPP FOR PRE-BREEDING DIRECTED TO THE NEEDS OF THE NORDIC-BALTIC REGION}

In the first Call of the PPP and in the decisions on funding it has been assumed that the now established activities can be 
carried forward also after the pilot phase, of course on the condition that the projects are successful and can be prioritised compared to other proposals in a future open Call. In order to make the responsible political bodies of the respective Nordic countries interested in a continuation of the PPP a positive outcome of the upcoming evaluation is, of course, a prerequisite. But it is also necessary to pinpoint and clarify the joint political issues for the Nordic countries for which their solution depend on the long-term development of plant breeding and where the PPP for Pre-breeding will be an important part of the tool-box. It is as important, however, that the plant breeding community can give examples on areas where joint pre-breeding efforts are needed and can make difference. In order to have an impact it is also necessary to make priorities in such a list. With the interest shown from the plant breeding community in the Baltic countries to participate in the Nordic PPP for Pre-breeding it is natural to include Baltic plant breeding in this process. The first step towards the development of a Concept note for Pre-breeding efforts directed to the needs of the Nordic-Baltic region was, thus, the workshop on this issue at the Conference celebrating the $75^{\text {th }}$ anniversary of State Stende Cereal Breeding Institute. The development of such a Concept note should also be seen in perspective of the increased interest of the European Commission in public breeding in order to support a knowledge and bio-based economy.

The workshop acknowledged that keywords in a description of the background are

- expected climate changes in a 20-30 year perspective;

- implications on crop production systems including yield stability with increased abiotic stresses, sustainable use of resources and durable resistances to pathogens and pests;

- market demands and changed importance of different crops;

- links to green growth and to a knowledge and bio-based economy;

- access to all technologies, including biotech, for main stream production under the concept of sustainable intensification;

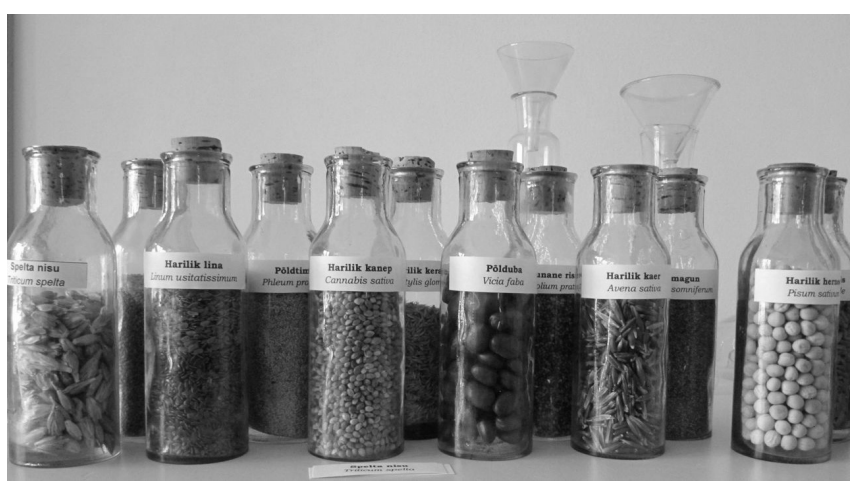

Collected seed samples in the gene bank at Jõgeva Plant Breeding Institute, Estonia. Picture taken during a visit to Baltic plant breeding entities, February $15-18,2010$.

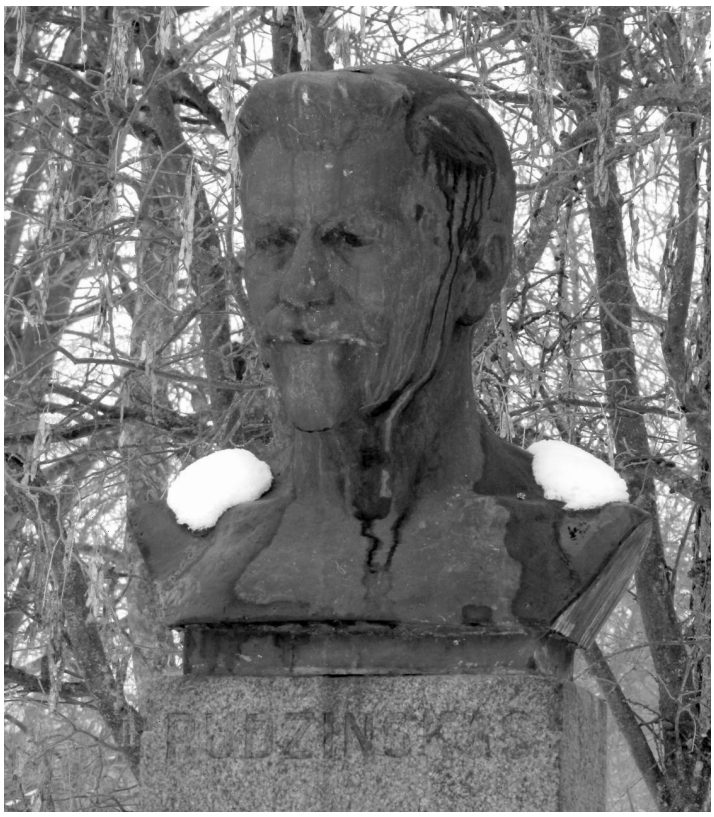

Monument to D. Rudzinskas. D. Ruzinskas was the teacher and mentor of N. I. Vavilov. Picture taken during a visit to Baltic plant breeding entities, February 15-18, 2010.

- specific needs for organic production and regionally adapted varieties;

and that keywords for the scope of needed efforts would include

- traits for food, feed and industrial uses with a clear preference for traits related to food security, nutrition and health;

- the economic importance of a given combination of crop and effort;

- crops of specific interest in the region;

- crops for which continued breeding for the region is foreseen.

For the further development of the PPP for Pre-breeding directed to the needs of the Nordic-Baltic region a number of different combinations of crops and efforts were discussed in the workshop, based upon the outlined background and scope. The crops discussed included cereals, oilseeds, protein crops, forages, potatoes, field vegetables, fruits and berries as well as energy and industrial crops. For each group of crops several important traits or efforts were brought into the discussion. Thus, it was strongly emphasised that there is a need to prioritise the most important examples among the mentioned targets in a Concept note on future prebreeding efforts to be developed by the plant breeding community. If not, there is a risk that the political sphere and authorities won't see the concept note as a realistic input. Since it can be foreseen that there will be demands on continued co-funding 50/50 from the breeding entities, the priorities must also reflect the willingness of breeding companies to participate. 


\section{LITERATURE}

Nilsson, A., von Bothmer, R. (2010). Measures to promote Nordic plant breeding. TemaNord 2010, $518 \mathrm{pp}$.

http://www-umea.slu.se/bibum/eref/index.cfm?redir=3714.
Public Private Partnership on pre-breeding (2011).

http://www.nordgen.org/index.php/skand/Vaexter/Innehaall/

Partnerskap-foer-pre-breeding/PPP-Public-Documents.

Ziemeḷvalstu Ministru padome ir apstiprinājusi publiskā un privātā sektora sadarbības programmu selekcijas materiāla izveidē. Tajā tiek uzaicināti arī Baltijas valstu speciālisti. Rakstā sniegts ieskats programmas uzdevumos. 